\title{
The Need Analysis of Chemistry Module Based on Guided Discovery to Facilitate Critical Thinking and Chemical Literacy Ability
}

\author{
Andini Desikasari Nuraisyah ${ }^{1 *}$, Sulistyo Saputro ${ }^{1}$, and Endang Susilowati ${ }^{1}$ \\ ${ }^{1}$ Postgraduate Programme of Chemistry Education, Faculty of Teacher Training and Education, Sebelas Maret \\ University, Ir. Sutami Street No. 36A, Surakarta, 57122, Indonesia \\ *Corresponding author. Email: andini.desikasari@gmail.com
}

\begin{abstract}
This research aims to find out how students and teachers need of chemistry modules based on guided discovery to improve critical thinking and chemical literacy ability. The research method used is qualitative. Data were collected through observation, interview, and questionnaire distribution. The subjects of this research were students of XI grade in three schools that contained 36 students of Senior High School 1 Ponorogo, 36 students of Senior High School 1 Badegan Ponorogo, and 30 students of Senior High School 1 Balong Ponorogo. Besides interviews were conducted with four chemistry teachers in the three schools in Ponorogo. The results showed that $82,35 \%$ of students stated that the development of a chemistry module based on guided discovery is needed. Students stated that the stages in guided discovery could guide them to understand the concepts being learned. There are $78,43 \%$ of students stated that the chemistry module based on guided discovery could help them to think more critically and improve their chemical literacy ability. It is because, the guided discovery could guide students to construct concepts, so learning activities are more meaningful and they more easily understand the lesson. Based on the results of the interviews, the four teachers from Senior High School 1 Ponorogo, Senior High School 1 Badegan Ponorogo, and Senior High School 1 Balong Ponorogo stated that the stages in guided discovery could train students' critical thinking and chemical literacy ability. Then, learning activities using guided discovery models will be carried out well if supported by the appropriate module.
\end{abstract}

Keywords: module, guided discovery, critical thinking, chemical literacy

\section{INTRODUCTION}

Nowadays, learning activity is expected to be able to apply components in 21 st-century learning. Learning in the 21 st-century trains students to be more active and independent in learning activities and the teacher as a facilitator who guides students [1,2,3]. One of the competencies in 21 st-century learning is critical thinking. Critical thinking is the ability to use ideas to think openly, collect, analyze, evaluate various information, and explain conclusions obtained logically [4,5]. Critical thinking requires good analytical and evaluation skills to make rational decisions and solve problems. Learn critical thinking makes students develop other skills, such as higher levels of concentration, deeper analytical skills, and better mind processing, train concentration to focus on problems. Besides critical thinking ability, the competency needed in 21st-century learning is literacy. Holman state in Shwartz, et al., [6], chemical literacy is the ability that consists of understanding chemical ideas, ideas about what chemists do, important skills, and chemical context.
According to Shwartz, et al., the ability of chemical literacy includes 4 aspects, namely (1) knowledge of chemical material and scientific ideas; (2) chemistry in context; (3) high-level learning skills; and (4) affective aspects [7]. In 21st century learning, students are not only required to be knowledgeable, but must be equipped with critical thinking skills, strong characters, and supported by the ability to utilize information and communication technology. Therefore, critical thinking and chemical literacy ability is an important competency that must be mastered by students.

The ability to think critically and chemical literacy is a characteristic of scientific attitudes that are the goals of chemistry education in secondary schools. Guidelines on how to teach students to think critically and to have good chemical literacy ability are important issues in education in Indonesia. An effort to develop 21st-century skills within learning chemistry can be done through the implementation of the 2013 Curriculum [8]. The characteristics of learning in the 2013 curriculum are the scientific approach, which is characterized by the development of abilities and skills in observing, asking, trying, reasoning, and communicating. One of the 
learning model based on a scientific approach that is recommended is guided discovery [9].

Guided discovery is a learning model based on discovery. According to Brunner in Mayer [10], in guided discovery-based learning, students are given a problem and the teacher provides instructions, direction, feedback, and examples to guide students in solving problems. Guided discovery learning is a model that guides and trains students to achieve active learning, gain knowledge, and build scientific concepts that they find for themselves [11]. The application of guided discovery learning can improve student learning outcomes in chemistry [12].

One of the materials in chemistry that is considered difficult and abstract is thermochemistry [13]. Thermochemistry is the study of the relationship between heat and chemical reaction. Thermochemistry may also be defined as the study of the quantity of heat absorbed or released by chemical reactions [14]. Thermochemistry is one chemical that is quite complex because it requires several concepts such as chemical reaction equations, stoichiometry, and hydrocarbons. The results of research on learning difficulties in thermochemistry materials include that (1) students find difficult to distinguish heat and temperature, (2) students find difficult to identify systems and environments in reactions that occur within the calorimeter, and (3) students find difficult to identify exothermic and endothermic reactions [15]. The results of the study revealed that guided discovery is more effective than conventional methods of enhancing student achievement in chemistry [16].

The stages in guided discovery are in accordance with critical thinking indicators. And to think critically students must have good chemical literacy ability. The matrix is arranged based on the syntax guided discovery according to Syah [17], aspects of critical thinking according to Facione [18], and aspects of chemical literacy according to Shwartz, et al. [7] presented in Table 1.

Table 1. Matrix based on syntax guided discovery, critical thinking, and chemical literacy ability

\begin{tabular}{|c|c|c|c|}
\hline No & Syntax Guided Discovery & Critical Thinking Indicators & Chemical Literacy Indicators \\
\hline 1 & Stimulation & $\begin{array}{l}\text { - Interpretation } \\
\text { Understand and express the meaning } \\
\text { phenomena energy change. }\end{array}$ & $\begin{array}{l}\text { - Understand and explain phenomena } \\
\text { energy change based on chemical } \\
\text { concepts. }\end{array}$ \\
\hline 2 & Identification problem & $\begin{array}{l}\text { - Analysis } \\
\text { Identify problems related to thermal } \\
\text { energy transfer or exothermic and } \\
\text { endothermic reactions. }\end{array}$ & $\begin{array}{l}\text { - High-level learning skill } \\
\text { Formulate problems related to thermal } \\
\text { energy transfer or exothermic and } \\
\text { endothermic reactions. }\end{array}$ \\
\hline 3 & Data collection & $\begin{array}{l}\text { - Interpretation } \\
\text { Design exothermic and endothermic } \\
\text { reaction experiments based on } \\
\text { illustrations or instructions. }\end{array}$ & $\begin{array}{l}\text { - Aspect Affective } \\
\text { Active in scientific inquiry activities, } \\
\text { showing enthusiasm in exothermic and } \\
\text { endothermic reaction experiments. } \\
\text { - Chemical content } \\
\text { Design and to do exothermic and } \\
\text { endothermic reaction experiments in } \\
\text { accordance with thermochemistry } \\
\text { concepts. }\end{array}$ \\
\hline 4 & Data Analysis & $\begin{array}{l}\text { - Analysis } \\
\text { Analyze experimental data on } \\
\text { exothermic and endothermic reactions } \\
\text { through guide questions. } \\
\text { Explanation } \\
\text { Explain, discuss, and state arguments } \\
\text { relating to the results of exothermic and } \\
\text { endothermic reaction experiments. } \\
\end{array}$ & $\begin{array}{l}\text { - High-level learning skill } \\
\text { Analyze experimental data on } \\
\text { exothermic and endothermic reactions } \\
\text { that observed. } \\
\text { - Chemical content } \\
\text { Analyze experimental data based on } \\
\text { understanding thermochemistry } \\
\text { concepts. }\end{array}$ \\
\hline 5 & Verification & 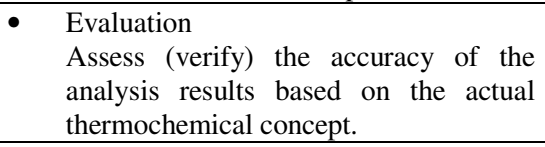 & $\begin{array}{l}\text { - Chemical content } \\
\text { Evaluate the results of data analysis } \\
\text { based on their chemical understanding. }\end{array}$ \\
\hline 6 & Generalization & $\begin{array}{l}\text { Inference } \\
\text { Make conclusions in accordance with } \\
\text { the concepts of exothermic and } \\
\text { endothermic reactions. }\end{array}$ & $\begin{array}{l}\text { - Chemical content } \\
\text { Make conclusions in accordance with } \\
\text { the concepts of exothermic and } \\
\text { endothermic reactions. } \\
\text { - Aspects of chemical context } \\
\text { Analyze the strategies and benefits of } \\
\text { thermochemical applications. }\end{array}$ \\
\hline
\end{tabular}


Based on the explanation above, guided discovery can be applied to train students' critical thinking and chemical literacy ability. The implementation of guided discovery in chemistry learning will be carried out well if supported by the competence of educators and the availability of teaching materials or modules. Through modules, teachers will more easily carry out learning and students will be more helped in learning. The development of a module is suitable as an alternative teaching material to measure students' particular abilities through constructivist learning strategies [19]. Based on the explanation above, this research is intended to make a preliminary analysis of the needs of students and teachers for thermochemistry modules based on guided discovery.

\section{METHOD}

This study used descriptive qualitative method. The purpose of this study was to explore the students' and teachers' needs of the chemistry module based on guided discovery. The subjects of this research were students of XI grade in three schools that contained 36 students of Senior High School 1 Ponorogo, 36 students of Senior High School 1 Badegan Ponorogo, and 30 students of Senior High School 1 Balong Ponorogo. Besides interviews were conducted with four chemistry teachers in the three schools in Ponorogo. Data were collected through observation, interview, and questionnaire distribution. The data were analyzed with the percentage calculation by the following formula.

Description:

$$
\mathrm{P}=\frac{n}{N} \times 100 \%
$$

$\mathrm{P}=$ Percentage score $\mathrm{n}=$ Numbered of scores obtained; $\mathrm{N}=$ Maximum score

The students' questionnaires consisted of 10 open-ended questions to find out their reasons for giving yes or no answer for each question. This questionnaire has been validated by experts. An example of a questionnaire for students presented in Table 2.

Table 2. Sample questions on the questionnaire

\begin{tabular}{|c|c|c|c|}
\hline \multirow{2}{*}{ Question } & \multicolumn{2}{|c|}{ Answer } & \multirow{2}{*}{ Reason } \\
\hline & Yes & No & \\
\hline $\begin{array}{l}\text { Do you use books, teaching } \\
\text { materials or modules as a learning } \\
\text { resource for thermochemical } \\
\text { material? Why? }\end{array}$ & & & \\
\hline $\begin{array}{l}\text { Do the teaching materials or } \\
\text { thermochemical modules you use } \\
\text { lead you to think critically (the } \\
\text { ability to think about information } \\
\text { and then process the information, } \\
\text { from identifying, analyzing, to } \\
\text { concluding to solve problems)? }\end{array}$ & & & \\
\hline
\end{tabular}

Then, the students' interview guideline covered 4 openended questions (1 question about teachers' method in the learning process, 1 question about learning materials, 1 question about the obstacle of students in understanding the material, and 1 question about students' needs. The interview aimed at finding out information about the process of learning activities and problems faced during learning. The teachers' interview guidelines comprised 20 open-ended questions about teaching-learning processes, teaching materials, students' skills, teachers' needs, and outcomes from the learning process.

\section{RESULTS AND DISCUSSION}

Based on observations can be obtained from data about the learning process carried out in three schools in Ponorogo. During the observation, the teacher used the discourse, discussion, and question and answer method. However, the learning activities are dominantly centered on the teacher. Students listen to the explanation of the material and are occasionally asked to express their opinions or arguments. Chemistry learning activities at the Senior High School focus on achieving product indicators, while process indicators that involve critical thinking ability are not trained. Therefore, student activities that describe critical thinking ability such as formulating problems, making hypotheses, analyzing, and concluding are not yet apparent. The questionnaire given to students was used to see students' needs for the thermochemistry module. The questionnaire contained 10 open-ended questions about learning material and students' needs for the module. In learning activities, students use books as a source of learning thermochemistry $(96.22 \%)$. Besides the textbooks provided by schools, $74.73 \%$ of students use supporting books such as worksheets learners (LKPD). From the description of the material in textbooks and worksheets, aspects of the content have been fulfilled, but $62.26 \%$ of students stated that there are limitations to the learning resources they use. $70,58 \%$ of students stated that they had difficulty studying thermochemistry materials using existing handbooks because the description of material were less contextual. This is caused, students cannot understand thermochemistry material easily $(75.79 \%)$, and according to students, the ideal learning material is a learning material that can guide gradually in finding concepts. The learning material that has been used has not guided them to think critically $(86.79 \%)$. The learning material already guides them to train chemical literacy ability through reading, writing, working on problems, and understanding material content $(63.24 \%)$. Students prefer to learn to use learning material that can guide gradually to understand thermochemistry material $(92.45 \%) .78 .43 \%$ of students state that chemistry modules that are appropriate to the stages of stimulation, problem identification, data collection, data analysis, verification, and conclusions can practice critical thinking and chemical literacy ability. Then, $82,35 \%$ of students stated that the development of a chemistry module based on guided discovery is needed because the stages in guided discovery could guide them to 
understand the concepts being learned. This is because guided discovery will develop the students' reasoning ability in finding out scientific concepts and growing their problem-solving capability [20].

The data collected from filling out the questionnaire was strengthened by several interviews with students. 20 students were randomly selected to be interviewed. Based on the results of the interview, $80 \%$ of students have difficulty understanding thermochemistry because in learning activities are only listening, taking notes, and doing the practice questions. Students are not guided to develop concepts through learning activities. Activities that involve student activity, for example, doing practicum is also very rarely done. In one semester, the average student does practicum activities once or twice, even some students have never done a practicum in the laboratory.

On the topic of thermochemistry, average students have difficulty with exothermic and endothermic reactions, as well as determining enthalpy changes based on the calorimetry method. $60 \%$ of students assume that the endothermic reaction undergoes a process of releasing heat so that the object cools. Meanwhile, on the topic of calorimetry, students have difficulty in determining the number of moles of substances that react or determine the change in enthalpy per mole of substances. As for the topic of calculating enthalpy change through Hess's Law, enthalpy change in standard formation, and average bond energy, the majority of students already understand it.

Besides containing some open questions, the questionnaire also contained three multiple choice questions that students had to work on. These questions aim to look at students' abilities in arrange problem formulations, interpreting and analyzing data, and making conclusions based on the problems presented. The problem presented is not specific to thermochemistry material, but rather to other material that is in general. One example of the problem being tested is presented in Table 3.

Based on the analysis of test results, $62.26 \%$ of students can formulate the problem formulation correctly, $18.87 \%$ of students can interpret and analyze data correctly, and $15.09 \%$ of students can make conclusions based on the problems presented. The results of the test show that students have critical thinking and chemical literacy ability in the low-moderate category. This can be caused, by the learning process students are not guided in the activities of developing concepts.

Based on interviews with four chemistry teachers, the teacher stated that the majority of learning activities took place using lecture, question and answer methods and did not use specific learning models. This is caused by the target material that has to be conveyed quite a lot over a certain period. With a variety of considerations, teachers are more likely to explain the material to students so that all material is conveyed, not inviting students to be involved in discovering the concept of thinking independently [21]. Thus, the process of learning activities undertaken does not support the ability to think critically. Whereas the aspect of chemical literacy is only limited to literacy in writing, reading, calculating, and understanding chemical content. For high category chemical literacy, students are not only able to write, read, calculate, and understand chemical content, but also apply their chemical understanding to solve problems and show interest in chemical issues.

To train critical thinking and chemical literacy ability, teachers must innovate in learning activities. This innovation can be done by applying the learning model suggested in the 2013 Curriculum, for example, guided discovery. By applying the guided discovery learning model, it is hoped that learning activities are centered on students, so that the teacher has a role to guide and become a facilitator in learning activities, not dominating. One of the reasons teachers have not implemented the guided discovery learning model in learning activities is not yet providing modules that are appropriate for the learning model. Some teachers make their handouts but they are not specific to certain learning models. The implementation of guided discovery learning models in the classroom will be optimal if there are modules that fit the guided discovery learning steps. All teachers stated that they need learning material based on guided discovery, so that it could support students' critical thinking and chemical literacy ability.

Table 3. One example problem on the questionnaire

\begin{tabular}{|c|c|}
\hline Question item & Answer choices \\
\hline $\begin{array}{l}\text { Take a look at the following distillation fractionation } \\
\text { of crude oil from petroleum drilling results! }\end{array}$ & $\begin{array}{l}\text { A. reduce the heating temperature below the } \\
\text { boiling point of the gas fraction } \\
\text { B. enlarge the heating temperature above the } \\
\text { boiling point of the lubricating oil fraction } \\
\text { C. enlarge the heating temperature above the } \\
\text { boiling point of the paraffin fraction } \\
\text { D. enlarge the heating temperature above the } \\
\text { boiling point of the diesel fraction } \\
\text { E. reduce the heating temperature below the } \\
\text { boiling point of the diesel fraction }\end{array}$ \\
\hline $\begin{array}{l}\text { Base } \\
\text { done }\end{array}$ & \\
\hline
\end{tabular}




\section{CONCLUSION}

The need analysis indicated that the school materials were not adequate for understanding chemistry. Understanding chemistry includes critical thinking skills and chemical literacy. Further, the teachers remained to use discourse, question and answer method which resulted in a teachercentered. Therefore, it is necessary to developed chemistry modules with the characteristics of a scientific approach. One learning model based on a scientific approach is guided discovery. Thus, the development of chemistry module based on guided discovery is one possibility to make students learn chemistry better. It is expected that this new kind of module could foster the students' critical thinking and chemical literacy ability with its strengths to meet the demand of the 21 st century.

\section{ACKNOWLEDGMENT}

This study was supported by Sebelas Maret University, Senior High School 1 Ponorogo, Senior High School 1 Badegan, Ponorogo and Senior High School 1 Balong, Ponorogo, Indonesia.

\section{REFERENCES}

[1] A. O. Akinbobola \& F. Afolabi, Constructivist practices through guided discovery approach : The effect on students' cognitive achievement in Nigerian senior secondary school physics, Eurasian Journal of Physics and Chemistry Education, 2(1) (2010) 16-25.

[2] Ansari \& S. K. Malik, Image Of An Effective Teacher in $21^{\text {st }}$ Century Classroom. Journal of Educational and Instructional Studies in the World, 3(4) (2013) 61-68.

[3] M. E. Udo, Effect of Guided-Discovery, StudentCentred Demonstration and the Expository Instructional Strategies on Students ' Performance in Chemistry. African Research Review, 4(16) (2010) 389-398.

[4] R. Duron, B. Limbach, \& W. Waugh, Critical Thinking Framework For Any Discipline. International Journal of Teaching and Learning in Higher Education, 17(2) (2006) 160-166.

[5] J. Moon, Critical thinking: An exploration of theory and practice, Routledge Taylor \& Francis Group, New York, 2008.

[6] Y. Shwartz, R. Ben-Zvi, \& A. Hofstein, The Importance of Involving High-school Chemistry Teachers in The Process of Defining the Operational Meaning of 'Chemical Literacy', International Journal of Science Education, 27(3) (2005) 323-344. DOI: $10.1080 / 0950069042000266191$

[7] Y. Shwartz, R. Ben-Zvi, \& A. Hofstein, The use of scientific literacy taxonomy for assessing the development of chemical literacy among high-school students, Chemistry Education Research and Practice, 7(4) (2006) 203-225. DOI: https://doi.org/10.1039/B6RP90011A

[8] D. Nastiti, S. B Rahardjo, E. Susanti VH, \& R. Perdana, The Need Analysis Of Module Development Based On Search, Solve, Create, And Share To Increase Generic Science Skills In Chemistry, Jurnal Pendidikan IPA Indonesia, 7(4) (2018) 428-434. DOI: https://doi.org/10.15294/jpii.v7i4.12393

[9] I. W. Redhana, Mengembangkan Keterampilan Abad Ke-21 dalam Pembelajaran Kimia, Jurnal Inovasi Pendidikan Kimia, 13(1) (2019) 2239-2253.

[10] R. E. Mayer, Should There Be a Three-Strikes Rule Against Pure Discovery Learning? The Case for Guided Methods of Instruction, American Psychologist, 59(1) (2004) 14-19. DOI: https://doi.org/10.1037/0003066X.59.1.14

[11] A. A. Carin, Teaching Science Through Discovery 8th. Ed, Pearson Prentice Hall, Inc, Upper Saddle River, New Jersey Columbus, Ohio, 1997.

[12] K. Fatokun \& P. Eniayeju, The Effect of Concept Mapping-Guided Discovery Integrated Teaching Approach on Chemistry Students' Achievement and Retention, Educational Research and Reviews, 9(22) (2014) 1218-1223. DOI: https://doi.org/10.5897/ERR2014.1848

[13] Y. Ayyildiz, \& L. Tarhan, The effective concepts on students' understanding of chemical reactions and energy, Hacettepe Egitim Dergisi, 42 (2012) 72-83.

[14] Effendy, A-Level Chemistry for Senior High School Students Volume 1A, Bayumedia, Malang, 2012.

[15] E. Yalçınkaya, O. Taştan, \& Y. Boz, High School Students' Conceptions about Energy in Chemical Reactions, Pamukkale Universitesi Eğitim Fakultesi Dergisi, 26 (2009) 1-11.

[16] O. Akani, Effect of Guided Discovery Method of Instruction And Students' Achievement in Chemistry at the Secondary School Level in Nigeria, International Journal of Scientific Research and Education, 05(02) (2017) 6226-6234. DOI: https://doi.org/http://dx.doi.org/10.18535/ijsre/v5i02.06

[17] M. Syah, Educational Psychology With A New Approach, PT Remaja Rosda Karya, Bandung, 2014.

[18] P. A. Facione, Critical Thinking: What It Is and Why It Counts, Insight Assessment, California, 2015. 
[19] R. Rufii, Developing Module on Constructivist Learning Strategies to Promote Students' Independence and Performance, International Journal of Education, 7(1) (2015) 18-28. DOI: 10.5296/ije.v7i1.6675

[20] B. S. Palupi, S. Subiyantoro, Rukayah, \& Triyanto, The Effectiveness of Guided Inquiry Learning (GIL) and Problem-Based Learning (PBL) for Explanatory Writing Skill, International Journal of Instruction, 13(1) (2020) 713-730. DOI:

https://doi.org/https://doi.org/10.29333/iji.2020.13146a

[21] D. A. Puspitasari, \& H. Nasrudin, Increasing Of Critical Thinking Skills Using Inquiry Learning Model In Sub Material Solubility And Solubility Product In Grade Xi RSBI Senior High School 1 Bojonegoro.

Unesa Journal of Chemical Education, 1(1) (2012) 7682. 